\title{
Vertical migration of dinoflagellates: model analysis of strategies, growth, and vertical distribution patterns
}

\author{
Rubao Ji ${ }^{1, *}$, Peter J. S. Franks ${ }^{2}$ \\ ${ }^{1}$ Department of Biology, Woods Hole Oceanographic Institution, Woods Hole, Massachusetts 02543, USA \\ ${ }^{2}$ Integrative Oceanography Division, Scripps Institution of Oceanography, University of California, San Diego, La Jolla, \\ California 92093-0218, USA
}

\begin{abstract}
Dinoflagellates demonstrate a variety of vertical migration patterns that presumably give them a competitive advantage when nutrients are depleted in the surface layer of stratified waters. In this study, a simple quota-based model was used to examine the relationships between the vertical migration pattern and internal nutritional status, and to assess how external environmental conditions, such as mixing layer depth (MLD) and internal waves, can influence these relationships. Dinoflagellates may form subsurface aggregations or conduct vertical migration (diel or non-diel) in response to their internal nutrient quota, but within a limited physiological parameter space. The model was implemented in a 1D (vertical) domain using an individual-based modeling approach, tracking the change in nutrient quota and the trajectory of many individual cells in a water column. The model shows that dinoflagellate cells might change from one vertical migration pattern to another when the external environmental conditions change. Using the average net growth rate as an index of fitness, 2 migration strategies, photo-/geotaxis vs. quota-based migration, were assessed with regard to MLD and internal wave regime. It was found that dinoflagellates might choose different migration strategies under different mixing/stratification regimes. In addition, under the same environmental conditions, different species might display unique vertical migration patterns due to inherent physiological differences. This study reveals the sensitivity of dinoflagellate vertical migration to biological and physical factors and offers possible explanations for the various vertical distributions and migration patterns observed in the field.
\end{abstract}

KEY WORDS: Dinoflagellates · Vertical migration $\cdot$ Model $\cdot$ Nitrogen quota Resale or republication not permitted without written consent of the publisher

\section{INTRODUCTION}

Vertical migration (VM) is a strategy that many dinoflagellates use to survive and potentially outcompete other phytoplankton groups, especially when nutrients become scarce in the surface layer of stratified waters (e.g. Holmes et al. 1967, Eppley et al. 1968, Cullen \& Horrigan 1981, MacIntyre et al. 1997). The competitive advantage of moving up and down in a stratified water column seems obvious: it allows dinoflagellates to have access to both the deep nutrient pool and to near-surface light required for photosynthesis, at different times of the day. Many studies have demonstrated that some bloom-forming dinoflagellates are capable of maintaining a relatively high nutrient uptake rate in a low-light or even completely dark environment (Eppley \& Harrison 1975, Heaney \& Eppley 1981, Paasche et al. 1984, Cullen 1985, Olsson \& Graneli 1991, Watanabe et al. 1991, Kudela \& Cochlan 2000, Fan \& Glibert 2005), thus allowing them to store extra nutrients by luxury uptake in the deep layer before ascending to the surface for photosynthesis.

The possible decoupling of nutrient uptake and photosynthesis leads to fluctuations of the internal nutritional status in cells at different phases of VM (Fraga et al. 1992). Such fluctuations of nutritional 
status are suggested to be an important cue for dinoflagellates to ascend or descend (Jones 1993, Kamykowski 1995, Broekhuizen 1999, Yamazaki \& Kamykowski 2000, Liu et al. 2001, Flynn \& Fasham 2002), where the cell nitrogen quota ( $\mathrm{N}: \mathrm{C}$ ratio) is often used to represent the internal nutritional status. When the internal $\mathrm{N}: \mathrm{C}$ ratio is above (below) certain threshold levels, cells are assigned to ascend (descend) regardless of the daylight cycle. The highest and lowest N:C ratios vary significantly among different dinoflagellate species (Fraga et al. 1992), suggesting that they have different capacities for carbohydrate storage and nitrogen luxury uptake. It remains unclear to what extent the cells will or can take advantage of their full capacities when they are exposed to either sub-surface high nutrient or surface high light conditions. This leads to the question of whether dinoflagellates will conduct simple taxis-directed or metabolism-influenced migration (Kamykowski \& Yamazaki 1997). Such a decisionmaking system in dinoflagellates, if it exists, appears to be closely related to their internal biochemical balances (e.g. the thresholds for internal quotas) and the external environment (e.g. light, nutrients; Kamykowski et al. 1998a, Yamazaki \& Kamykowski 2000). Models with fixed threshold levels, usually represented as certain fractions of maximum or minimum $\mathrm{N}$ :C ratios (e.g. Broekhuizen 1999, Liu et al. 2001), may work well for a given species under certain model settings, but are likely not applicable to systems with different dinoflagellate populations and environmental conditions.

The rhythms of dinoflagellate vertical migration, usually inferred from the day/night variation of vertical distribution (Kamykowski et al. 1998b), might be controlled by phototactic, geotactic, and chemotactic responses of dinoflagellates under different environmental conditions (see review by Pearre 2003 and references therein). Intuitively, diel VM (DVM) seems to be a 'favorable' strategy for dinoflagellates to adopt. Organisms ascend by phototaxis during the day and descend by geotaxis at night, allowing them to take full advantage of nutrient and light resources at different times of the day. This type of day/night circadian rhythm has been frequently observed in both laboratory (e.g. Eppley et al. 1968, Cullen et al. 1985, Watanabe et al. 1991, MacIntyre et al. 1997) and natural conditions (e.g. Eppley \& Harrison 1975, Eppley et al. 1984, Villarino et al. 1995, Fauchot et al. 2005). However, numerous studies have also suggested that the vertical profiles of many dinoflagellate species cannot be explained by a simple DVM pattern. For example, Townsend et al. $(2001,2005)$ reported a bi-modal vertical distribution of Alexandrium sp. in the Gulf of Maine, with high concentrations near both the surface and the pycnocline regions, but low in between. This distribution pattern implies that dinoflagellate cells may perform asynchronous VM (AVM) with a period longer than $1 \mathrm{~d}$. Moreover, the existence of persistent subsurface maxima of dinoflagellates near the pycnocline/nutricline has also been widely reported (e.g. Cullen \& Horrigan 1981, Eppley et al. 1984, Holligan et al. 1984, Townsend et al. 2001, 2005, Kononen et al. 2003), indicating that some species of dinoflagellate simply stop migrating under certain environmental conditions (although active swimming is still required to maintain a particular depth without being dispersed by mixing). For the present discussion, subsurface aggregation is regarded as a special vertical migration pattern.

In this study, we hypothesize that dinoflagellate cells can choose their migration strategies in response to their internal physiological status, which is regulated by external environmental conditions. We examined the necessary conditions for cells to exhibit DVM, AVM, or subsurface aggregation based on: (1) quotaand light-regulated cell growth and respiration; and (2) nutrient uptake (affected by ambient nutrient concentration, half saturation constant, and cell quota). To explore the possible influences of external environmental factors, numerical experiments were conducted to investigate the possible change of VM pattern in response to different mixing depths, and the impact of semi-diurnal internal tidal waves. The main purposes of this modeling study were to seek an explanation for the existence of variants of the VM pattern observed in both laboratory and natural conditions, and to demonstrate the sensitivity of VM to the complex interactions between cell physiological processes and the external environment.

\section{QUOTA-BASED MODEL}

Model formulation. We assume the amount of carbon $C$ in a dinoflagellate cell to be increased by growth $\mu\left(\mathrm{d}^{-1}\right)$ and decreased by respiration $\lambda\left(\mathrm{d}^{-1}\right)$ :

$$
\mathrm{d} C / \mathrm{d} t=(\mu-\lambda) C
$$

The amount of nitrogen $N$ in the cell is controlled by the amount of internal carbon and nitrogen uptake rate per unit carbon, $V\left(\mu \mathrm{g} \mathrm{N}[\mu \mathrm{g} \mathrm{C} \mathrm{d}]^{-1}\right)$,

$$
\mathrm{d} N / \mathrm{d} t=V C
$$

The cell nitrogen quota $Q$ is defined as the amount of nitrogen per unit carbon, which is equivalent to the $N: C$ ratio ( $\mu \mathrm{g} \mathrm{N} \mu \mathrm{g} \mathrm{C}^{-1}$ ). The change of $Q$ can then be described as:

$$
\begin{aligned}
\mathrm{d} Q / \mathrm{d} t= & \mathrm{d}(N: C) / \mathrm{d} t= \\
& -(\mu-\lambda)(N: C)+V=-(\mu-\lambda) Q+V
\end{aligned}
$$


From the first term on the right hand side, if biomass $C$ increases and the total nitrogen content in a cell stays the same, $Q$ decreases proportionately.

The growth rate $\mu$ is a function of the maximum specific growth rate $\mu_{\max }$ regulated by the cell nitrogen quota and light,

$$
\begin{aligned}
\mu=\mu_{\max } f(Q) f(I)= & \mu_{\max }\left(1-\frac{Q_{\min }}{Q}\right) \tanh \left(\alpha I / \mu_{\max }\right)= \\
& \mu_{\max }\left(1-\frac{Q_{\min }}{Q}\right) \tanh (\tilde{\alpha} I)
\end{aligned}
$$

The quota limitation, $f(Q)$, follows Droop's (1968) formula with a minimum cell nitrogen quota $Q_{\min }$. Light limitation, $f(I)$, follows Jassby \& Platt's (1976) photosynthesis-irradiance relationship. The initial slope of the growth-irradiance curve is $\alpha\left(\mathrm{d}^{-1}\left[\mu\right.\right.$ Ein $\mathrm{m}^{-2}$ $\left.\mathrm{s}^{-1}\right]^{-1}$ ), and $I$ is the photosynthetically available radiation PAR $\left(\mu\right.$ Ein $\left.\mathrm{m}^{-2} \mathrm{~s}^{-1}\right)$ at the local depth. Here, $\tilde{\alpha}$ is used to represent the value of $\alpha / \mu_{\text {max }}$, corresponding to the slope of growth-irradiance curve when $\mu_{\max }$ is normalized to 1 .

The respiration rate $\lambda$ is assumed to be a constant fraction of $\mu_{\max }$ under different cell quota and light conditions for the purpose of model simplification, with an understanding that the respiration rate of dinoflagellates might depend on internal and external factors, such as light intensity (Prezelin 1992) and nitrogen assimilation (Geider et al. 1998).

Nitrogen uptake $V$ is controlled by the ambient light intensity, nitrogen concentration, and cell nitrogen quota. The latter 2 terms can be described by Michaelis-Menten kinetics and a linear relationship, respectively. The term $V$ can then be written as:

$$
V=V_{\mathrm{m}} g(I) \frac{N}{\mathrm{~K}_{N}+N} \frac{Q_{\max }-Q}{Q_{\max }-Q_{\min }}
$$

where $V_{\mathrm{m}}\left(\mu \mathrm{gN}[\mu \mathrm{gC} \mathrm{d}]^{-1}\right)$ is the maximum uptake rate, $N$ is the ambient nitrogen concentration, and $\mathrm{K}_{N}$ is the half saturation constant. $Q_{\max }$ and $Q_{\min }$ represent the physiological upper and lower limits of the cell quota $Q$. Light limitation of nitrogen uptake is given by $g(I)$, and follows the tanh functional response of growth to light but allows dark nitrogen uptake:

$$
g(I)=g_{0}+\left(1-g_{0}\right) \tanh (\tilde{\alpha} I)
$$

Here, $g_{0}$ represents dark uptake, with a value ranging from 0 to 1 . If $g_{0}=0, f(I)=g(I)$; if $g_{0}=1$, then the maximum nitrogen uptake rate is light independent. Notice that $g(I) \geq f(I)$ under the same light intensity.

Eq. (3) can be rewritten including the terms discussed above:

$$
\begin{array}{r}
\frac{\mathrm{d} Q}{\mathrm{~d} t}=V_{\mathrm{m}} \frac{N}{\mathrm{~K}_{N}+N} \frac{Q_{\max }-Q}{Q_{\max }-Q_{\min }} g(I) \\
-\mu_{\max }\left(Q-Q_{\min }\right) f(I)+\lambda Q
\end{array}
$$

When nitrogen is saturating, uptake is equal to $V_{\mathrm{m}}$; using $\Delta Q$ for $\left(Q_{\max }-Q_{\min }\right)$, Eq. (7) can then be simplified to:

$$
\frac{\mathrm{d} Q}{\mathrm{~d} t}=V_{\mathrm{m}} \frac{Q_{\max }-Q}{\Delta Q} g(I)-\mu_{\max }\left(Q-Q_{\min }\right) f(I)+\lambda Q
$$

Migration behaviors, cues, and dynamics. If a cell's internal nitrogen quota drives VM, then we would expect cells to ascend once their quota $Q$ has increased sufficiently due to nutrient uptake at depth, and to descend when the quota has decreased sufficiently due to photosynthesis near the surface. To understand the potential for different VM behaviors, we need to understand the time scales over which cells can reach a threshold quota for $Q$ that will initiate the ascent or descent phase of the VM. To calculate these time scales as functions of the physiological parameters, we set $\sigma$ and $\gamma$ as threshold coefficients for descending and ascending, respectively: cells descend if $Q<$ $\sigma Q_{\min }$ and ascend if $Q>\gamma Q_{\max }$. The 2 time scales are $\tau_{\text {dark, }}$ the time scale for nighttime processes to drive $Q>\gamma Q_{\max }$, and $\tau_{\text {light, }}$ the time scale for daytime processes to drive $Q<\sigma Q_{\min }$ (see Appendix 1 for a detailed derivation):

$$
\begin{gathered}
\tau_{\text {dark }}=-\left(\frac{V_{\mathrm{m}}}{\Delta Q}-\lambda\right)^{-1} \ln \left[\frac{\frac{V_{\mathrm{m}}}{V_{\mathrm{m}}-\lambda \Delta Q}-\gamma}{\frac{V_{\mathrm{m}}}{V_{\mathrm{m}}-\lambda \Delta Q}-\frac{Q_{\min }}{Q_{\max }} \sigma}\right] \\
\tau_{\text {light }}=-\left(\mu_{\max }-\lambda\right)^{-1} \ln \left[\frac{\sigma-\frac{\mu_{\max }}{\mu_{\max }-\lambda}}{\frac{Q_{\max }}{Q_{\min }} \gamma-\frac{\mu_{\max }}{\mu_{\max }-\lambda}}\right]
\end{gathered}
$$

From Eqs. (9) and (10), we can see that both $\tau_{\text {dark }}$ and $\tau_{\text {light }}$ are shorter with higher $V_{\mathrm{m}} / \Delta Q$ and $\mu_{\text {max }}$, respectively (Fig. 1). Cells with higher maximal uptake and growth rates can satisfy the requirement for the initiation of vertical migration (upward or downward) more rapidly. In contrast, $\tau_{\text {dark }}$ decreases with increasing respiration rate $\lambda$, while $\tau_{\text {light }}$ increases with increasing $\lambda$. Since respiration tends to increase $Q$ by decreasing the carbon content of the cell, a higher respiration rate will allow a more rapid attainment of the cell nitrogen quota $\left(\gamma Q_{\max }\right)$ in the dark, thus shortening $\tau_{\text {dark }}$. Because respiration works against photosynthesis and slows the decrease of $Q$ in the light, $\tau_{\text {light }}$ increases with respiration rate.

For DVM, we would expect that $\tau_{\text {dark }}$ and $\tau_{\text {light }}$ would each be about $0.5 \mathrm{~d}$. Dinoflagellates tend to grow fairly slowly $\left(\mu_{\max }<1.0\right.$ to $\left.2.0 \mathrm{~d}^{-1}\right)$; thus, achieving a $\tau_{\text {light }}=$ $0.5 \mathrm{~d}$ requires a very low respiration rate, and/or a small difference between $\gamma$ and $\sigma$ (i.e. small changes in $Q_{i}$ Fig. 1). While smaller values of $\tau_{\text {light }}$ occur at very high $\left(\mu_{\max }>3 \mathrm{~d}^{-1}\right)$ growth rates, these rates are unreal- 

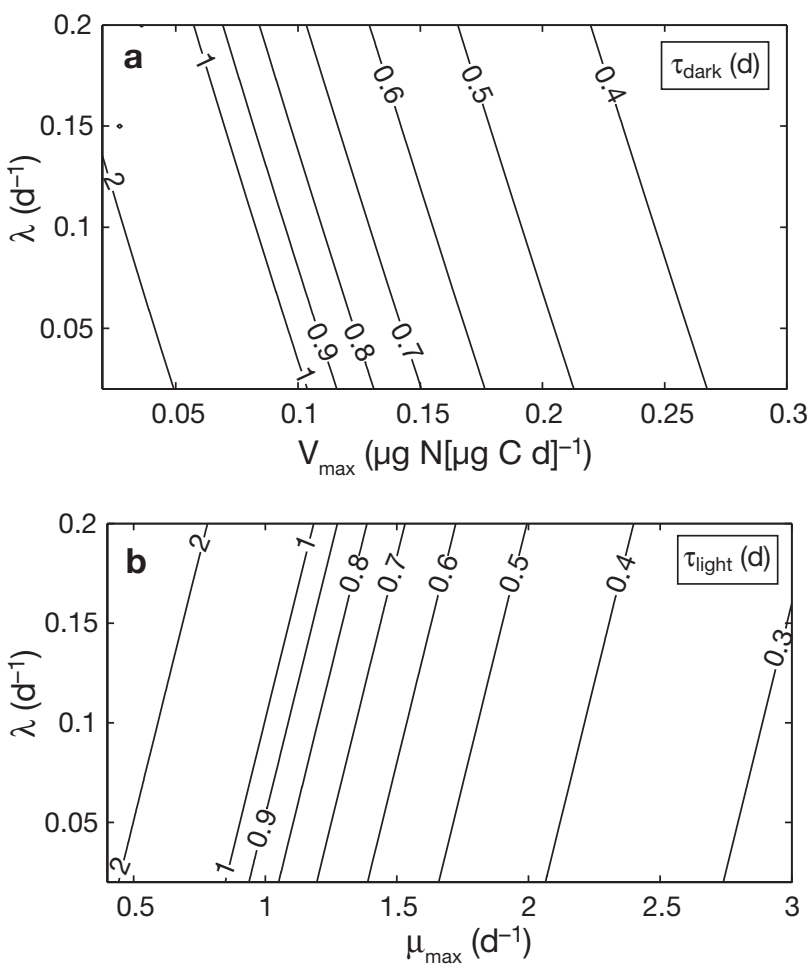

Fig. 1. (a) Contour plot of $\tau_{\text {dark }}$ for a range of $V_{\mathrm{m}}$ and $\lambda$ based on Eq. (9); (b) contour plot of $\tau_{\text {light }}$ for a range of $\mu_{\max }$ and $\lambda$ based on Eq. (10). Note that fixed values of the other parameters (Set A, Table 1) were used in both plots

istic for most dinoflagellates (Smayda 1997). If the change in $Q$ required to drive vertical migration is very small, it suggests that DVM might not be driven by internal biochemical stores, but rather by geotactic or phototactic responses. Alternatively, individual dinoflagellates may not follow a diel rhythm, but perform their migrations with periodicities of several days; the cumulative population response may still appear as a DVM.

Cells may also form a subsurface layer near the nitracline, while still satisfying the quota requirement $(Q<$ $\left.\gamma Q_{\max }\right)$. There are 2 possible ways to keep $\left.Q<\gamma Q_{\max }: 1\right)$ by maintaining a low internal $N$ store, and/or 2) by increasing the internal $C$ pool. Cells with low internal nitrogen concentrations must stay in nitrogen-rich subsurface waters to take up nitrogen before they can move upward for photosynthesis. Similarly, cells will remain subsurface if the local light intensity is sufficient for photosynthesis, while maintaining the nitrogen quota to be less than the threshold for ascent $\left(\gamma Q_{\max }\right)$. Thus, a necessary condition for the formation of subsurface layers is that the dinoflagellates have a relatively high maximum growth rate $\mu_{\max }$ and low nitrogen uptake rate (see Appendix 1 for details), such that

$$
\frac{V_{\mathrm{m}}}{Q_{\min } \mu_{\max }} \leq \frac{(\gamma-1 / \varepsilon)(\varepsilon-1)}{(1-\gamma)}
$$

where $\varepsilon=Q_{\max } / Q_{\min }$. Higher $\gamma$ and $\varepsilon$, equivalent to higher luxury uptake capacity, tend to increase the possibility of this condition being satisfied. Moreover, if nitrogen uptake is more light-dependent than growth, less nitrogen will be taken up in the low-light subsurface environment, which will facilitate the satisfaction of Eq. (11).

External environmental conditions, such as the mixing layer depth and internal wave regime, are likely to influence the subsurface irradiance. As a result, dinoflagellate cells may respond differently to different environments, shifting from subsurface aggregation to DVM or other migration strategies. In addition, migrations may be associated with dinoflagellate photo responses: if the surface light intensity is too high, cells may descend to a more optimal depth. These scenarios will be explored in the following numerical experiments.

\section{NUMERICAL EXPERIMENTS}

To explore dinoflagellate responses to physical forcings, numerical experiments were conducted in a 1D (vertical) domain. An individual-based model (IBM) based on Eq. (8) computed the change of the internal nitrogen quota and the vertical trajectories of individual cells. The vertical distributions of dissolved nitrogen and vertical mixing coefficient were prescribed as functions of the mixed-layer depth (MLD). The model assumed that both the mixing and nitrogen profiles (see below) did not change during the simulation period $(\leq 7 \mathrm{~d})$.

An important assumption for this IBM is that cells do not change their $Q$ when they divide. Rather, the cells simply split into 2 cells with same amount of carbon and nitrogen in each cell in the same ratio as the parent cell. Instead of explicitly following the cell-division process, the model treats the 2 daughter cells after division as a single super cell (the 'super individual-based model'). Using this technique, the total particle number will remain the same during the modeling period.

\section{Model environment}

For the purpose of this numerical experimental study, the vertical profiles for nitrogen and mixing coefficient (diffusivity) were prescribed. Nitrogen varied from low concentrations in the mixing layer to high concentrations in the deep nitrogen pool below the pycnocline:

$N(z)=$

$0.5 \times\{1-\tanh [\beta(z-D)]\}\left(N_{\max }-N_{\min }\right)+N_{\min }$ 
where $N(z)$ is the nitrogen concentration at depth $z$. The sharpness of the nitracline at depth $D$ is determined by $\beta$, with a higher $\beta$ creating a steeper nitrogen gradient between the surface mixing layer and the deep layer. $N_{\max }$ and $N_{\min }$ represent the maximum (deep) and minimum (surface) nitrogen concentrations, respectively (Fig. 2).

The vertical eddy diffusivity profile of a stratified water column is prescribed as a normal distribution function:

$$
K(z)=K_{\mathrm{s}} \exp \left[-\frac{(z-0.5 D)^{2}}{c D}\right]+K_{\mathrm{b}}
$$

where $K(z)$ is the eddy diffusivity at depth $z$ (Fig. 2). The steepness of the decrease in $K$ from the surface is determined by $c$, and the depth of the subsurface maximum by $D . K_{\mathrm{s}}$ and $K_{\mathrm{b}}$ represent maximum and background diffusivities, respectively.

To explore the impact of internal waves on the vertical migration pattern, we used a simple semidiurnal internal tidal wave (period $=12 \mathrm{~h}$ ), in a 2-layered system separated by a strong pycnocline. Since this study focused on vertical processes, only vertical movements of cells were considered, recognizing that internal

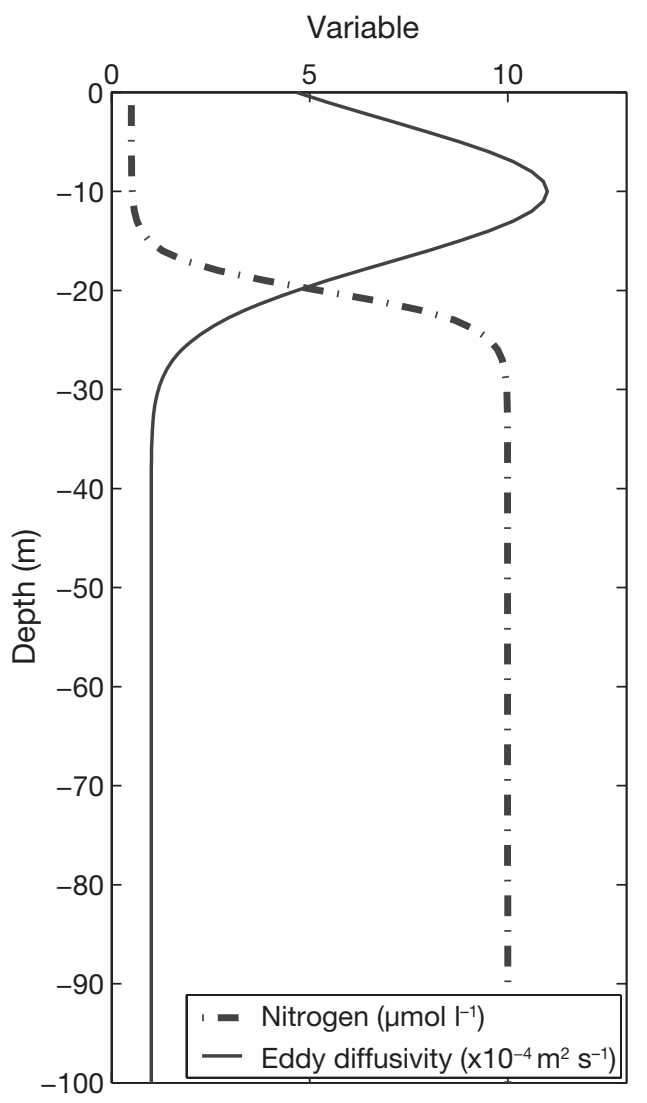

Fig. 2. Vertical profile of nitrogen (broken line) and eddy diffusivity (solid line) in a model water column with a $20 \mathrm{~m}$ MLD waves are typically $2 \mathrm{D}$. The vertical velocities at the surface and the bottom boundaries were 0 . One caveat of our 1D model is that the horizontal movement of water parcels is neglected; thus, no divergences and convergences at the surface and bottom were included in the model.

The motion of the interface of mean depth $z_{\mathrm{m}}$ can be described by a simple sine wave, propagating with frequency $\omega$, and horizontal wavenumber $k$, in the $x$ direction:

$$
z=z_{\mathrm{m}}+\operatorname{asin}(k x-\omega t)
$$

where $a$ is the amplitude of the motion, and $t$ is time. The vertical velocities, $w_{\mathrm{i}}(z)$, decrease linearly from the pycnocline (interface) to both the surface and the bottom:

$$
\begin{aligned}
& w_{\mathrm{i}}(z)=-a \cos (k x-\omega t)\left(z / z_{\mathrm{p}}\right), \text { if } z<z_{\mathrm{p}} \\
& w_{\mathrm{i}}(z)=-a \cos (k x-\omega t)(H-z) /\left(H-z_{\mathrm{p}}\right), \text { if } z>z_{\mathrm{p}}
\end{aligned}
$$

where $z_{\mathrm{p}}$ is the location of pycnocline at time $t$, and $H$ is the total water depth. These 2 equations are similar to those used by Kamykowski (1974) and Franks (1997).

A total of 1000 individual cells were released in each numerical experiment. Each individual cell moved vertically from depth $z_{n}$ at time step $n$ to $z_{n+1}$ in time $\delta t$, according to

$$
z_{n+1}=z_{n}+\left[w_{\mathrm{b}}\left(z_{n}\right)+w_{\mathrm{i}}\left(z_{n}\right)\right] d t+\tilde{\omega}
$$

where $w_{\mathrm{b}}\left(z_{n}\right)$ and $w_{\mathrm{i}}\left(z_{n}\right)$ are the swimming speeds and internal wave-driven water motion, respectively, at depth $z_{n}$. A hyperbolic tangent function (following Franks 1992) was used to describe the migration velocity towards a particular depth, $z_{0}$ :

$$
w_{\mathrm{b}}(z)=w_{\max } \tanh \left[\varphi\left(z-z_{0}\right)\right]
$$

where $\varphi$ is a scaling parameter determining the distance over which swimming speed decreases as the cells approach a target depth $z_{0}$. The determination of $z_{0}$ depends on the migration strategies chosen by cells. For quota-based migration, cells will move between the surface and subsurface (2 target depths) as the internal cell quota changes; $z_{0}$ is 0 for cells moving upward and is MLD for cells moving downward. For the photo-/geotaxis strategy, $z_{0}$ is 0 during the day and MLD at night. The value of $z_{0}$ will change in the high light avoidance strategy (Case 3 in the 'Numerical experiments - Case studies' section below).

The term $\tilde{\omega}$ is the vertical displacement caused by vertical diffusion, and can be described as a random walk process. Because the vertical diffusivity was not vertically homogeneous, the following formula was used to avoid unrealistic accumulation of cells near the region of low diffusivity (Visser 1997):

$$
\tilde{\omega}=K^{\prime}\left(z_{n}\right) \delta t+R\left\{2 K\left[z_{n}+0.5 K^{\prime}\left(z_{n}\right) \delta t\right] \delta t\right\}^{1 / 2}
$$


where $R$ is a standard Gaussian probability density function, and $K^{\prime}\left(z_{n}\right)$ is the first derivative of diffusivity at depth $z_{n}$ (see also Ross \& Sharples 2004).

To compare the growth potential (a proxy for 'fitness') of dinoflagellate cells with different migration strategies, we calculated the average net growth rate (ANGR). The carbon-specific rate of change of cellular carbon is:

$$
\xi(t)=\frac{1}{C} \frac{\mathrm{d} C}{\mathrm{~d} t}=\mu-\lambda=\mu_{\max }\left(1-\frac{Q_{\min }}{Q}\right) \tanh \left(\alpha I / \mu_{\max }\right)-\lambda
$$

For each cell, the total carbon biomass $C_{T}$ at the end of model run time $T$ is

$$
C_{T}=C_{0} \mathrm{e}^{\int_{0}^{T} \xi(t) \mathrm{d} t}
$$

where $C_{0}$ is the initial biomass. The ANGR is then the proportion of carbon added during time $T$ :

$$
\mathrm{ANGR}=\frac{1}{T}\left(\frac{C_{T}-C_{0}}{C_{0}}\right)=\frac{1}{T}\left[\mathrm{e}^{\int_{0}^{T} \xi(t) \mathrm{d} t}-1\right]
$$

\section{Case studies}

Case 1: MLD and migration pattern

There are significant temporal and spatial variations in the MLDs in coastal oceans. In this experiment, we explored 2 cases with MLDs of $10 \mathrm{~m}$ and $20 \mathrm{~m}$ when internal waves were not included. These MLDs correspond to about 22 and $4 \%$ of the surface light intensity with a diffuse attenuation coefficient $\left(K_{\text {ext }}\right)$ of $0.15 \mathrm{~m}^{-1}$. Obviously, if the vertical motion caused by internal tidal waves is considered, the MLDs vary periodically with time.

For both the 10 and $20 \mathrm{~m}$ MLD cases, a subsurface maximum of dinoflagellates was produced by this model when the physiological parameters listed in Table 1 (Set A) were applied. An example is given for the $10 \mathrm{~m}$ case (Fig. 3), in which the cells were concentrated near the pycnocline, with some small mixinginduced dispersion. The parameter values (Set A) satisfy the conditions of Eq. (11) for the formation of a subsurface layer, with a relatively high growth rate but low uptake rate. However, the model is quite sensitive to the choice of those parameters: a slight increase in the uptake rate will cause a shift from a subsurface aggregation to an AVM pattern (results not shown).

Satisfying the quota requirements does not mean that cells will achieve their maximal growth potential over a given period of time. With different MLDs, the nitrogen and light profiles vary correspondingly. As a result, potential relationships exist between MLDs and ANGR, which might affect the vertical migration

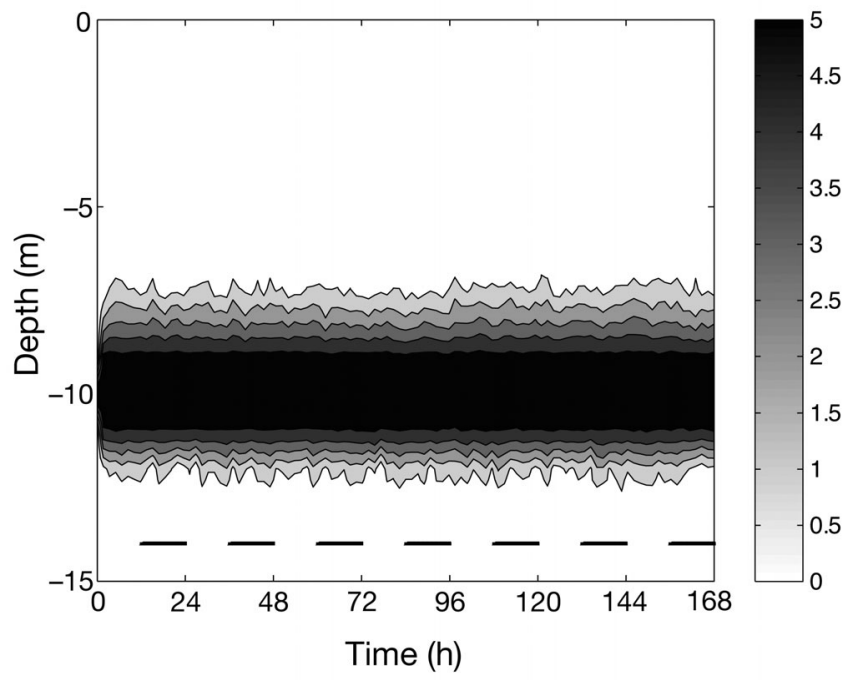

Fig. 3. Formation of a subsurface layer of dinoflagellates cells near a $10 \mathrm{~m}$ pycnocline. The values represented by the shade bar are $\log$ transformed using $\ln (\#+1)$ where \# is the no. of cells in a $1 \mathrm{~m}$ vertical bin. Black bars at the bottom of the plot represent nighttime

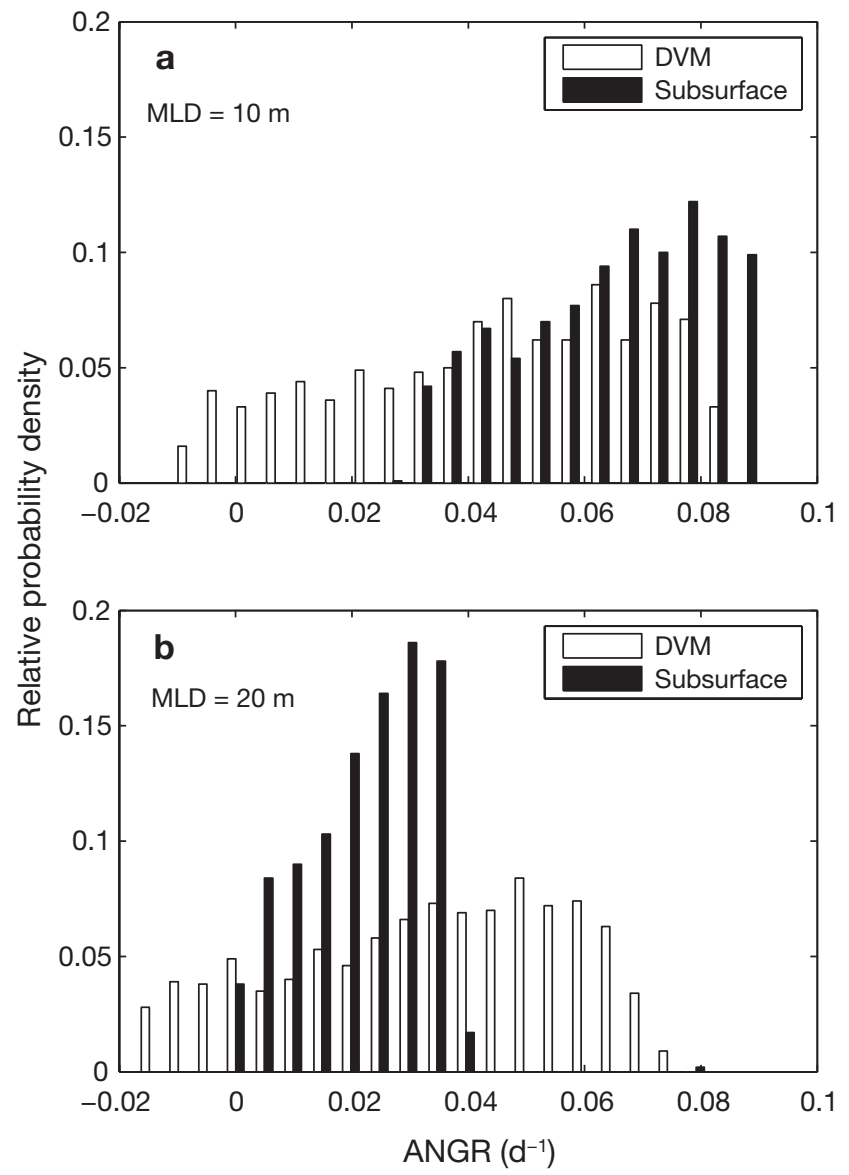

Fig. 4. Relative probability density functions (pdf) of average net growth rate (ANGR) for cells with DVM and subsurface aggregation VM patterns. Mixed layer depth: (a) MLD = $10 \mathrm{~m}$; (b) $\mathrm{MLD}=20 \mathrm{~m}$ 
Table 1. Physiological parameters used in the numerical experiments

\begin{tabular}{|c|c|c|c|c|}
\hline $\begin{array}{l}\text { Para- } \\
\text { meter }\end{array}$ & Description & Unit & Set A & Set B \\
\hline$Q_{\min }$ & Minimum cell quota & $\mu \mathrm{g} \mathrm{N} \mu \mathrm{g} \mathrm{C}^{-1}$ & 0.06 & 0.06 \\
\hline $\mathrm{Q}_{\max }$ & Maximum cell quota & $\mu \mathrm{g} \mathrm{N} \mu \mathrm{g} \mathrm{C}^{-1}$ & 0.24 & 0.24 \\
\hline$\alpha$ & $\begin{array}{l}\text { Growth-irradiance } \\
\text { curve initial slope }\end{array}$ & $\mathrm{d}^{-1}\left(10^{-3} \mu\right.$ Ein $\mathrm{m}^{-}$ & $\begin{array}{l}5.0 \\
\left.\mathrm{n}^{-2} \mathrm{~s}^{-1}\right)^{-1}\end{array}$ & ${ }_{1}^{3.4}$ \\
\hline$\mu_{\max }$ & Maximum growth rate & $\mathrm{d}^{-1}$ & 0.42 & 1.5 \\
\hline$V_{\mathrm{m}}$ & Maximum uptake rate & $\mu \mathrm{g} \mathrm{N}(\mu \mathrm{g} \mathrm{C} \mathrm{d})^{-1}$ & 0.05 & 0.1 \\
\hline$\sigma$ & $\begin{array}{l}\text { Threshold coefficient } \\
\text { for descending }\end{array}$ & Dimensionless & 1.8 & 1.8 \\
\hline$\gamma$ & $\begin{array}{l}\text { Threshold coefficient } \\
\text { for ascending }\end{array}$ & Dimensionless & 0.7 & 0.6 \\
\hline$\lambda$ & Respiration rate & $d^{-1}$ & 0.04 & 0.15 \\
\hline$g_{0}$ & Dark uptake offset & Dimensionless & 0.1 & 0.6 \\
\hline
\end{tabular}

strategies adopted by dinoflagellate cells. To examine those relationships, comparisons were made between cells with a quota-based migration strategy (remaining subsurface) and with a photo-/geotaxis strategy (DVM). For both strategies, the cells' growth- and uptake-related parameters were kept the same. As shown in the relative probability density of cells with different ANGR, cells staying subsurface have higher ANGR than cells with a simple DVM when the MLD is relatively shallow (10 m case, Fig. 4a), but the opposite is found when the MLD is $20 \mathrm{~m}$ (Fig. $4 \mathrm{~b}$; Mann-Whitney $U$-test, $\mathrm{p}<0.01$ ). This is not surprising: when MLDs become deeper, less light reaches the bottom of the mixing layer. Therefore cells conducting DVM will be able to overcome the light limitation by relaxing the quota constraints and will outcompete cells forming a layer at the MLD. On the other hand, if MLDs are shallow enough - such that cells will be able to attain near-optimal light intensities for photosynthesis even when they are near the pycnocline-then the quota-based strategy has obvious advantages due to the high local dissolved nitrogen concentrations that allow cells to fully utilize their luxury uptake and growth potentials. Notice that in both cases with different MLDs, DVM gives a much broader distribution of ANGR, reflecting the more diverse light and nutrient conditions cells experience when they conduct DVM. This is a consequence of attempting to complete a DVM cycle in a turbulent environment where vertical diffusion can work both for and against directed swimming. The mean ANGR for cells conducting DVM is higher in a $10 \mathrm{~m}$ MLD than a $20 \mathrm{~m}$ MLD and is the result of increased frequencies of cells with high ANGRs that completed the DVM cycle successfully (the right-hand tail of the probability density distribution).

For a given MLD, dinoflagellate cells may also exhibit AVM or DVM instead of forming subsurface aggregations. As shown earlier, quota-based DVM will only occur for a very limited physiological parameter space (large growth rate and small difference between the threshold quotas for ascending and descending), whereas AVM may occur over a much wider parameter space due to the relaxation of the time constraint. Fig. 5 shows one realization of AVM when the MLD is $20 \mathrm{~m}$ using parameter Set B (Table 1). Compared to the subsurface aggregation case (Set A), both the maximum growth rate $\left(\mu_{\max }\right)$ and maximum nitrogen uptake rates $\left(V_{\mathrm{m}}\right)$ of the dinoflagellate cells were increased, while $\gamma$ was decreased slightly, allowing the cells to ascend after achieving a relatively lower quota thresh-
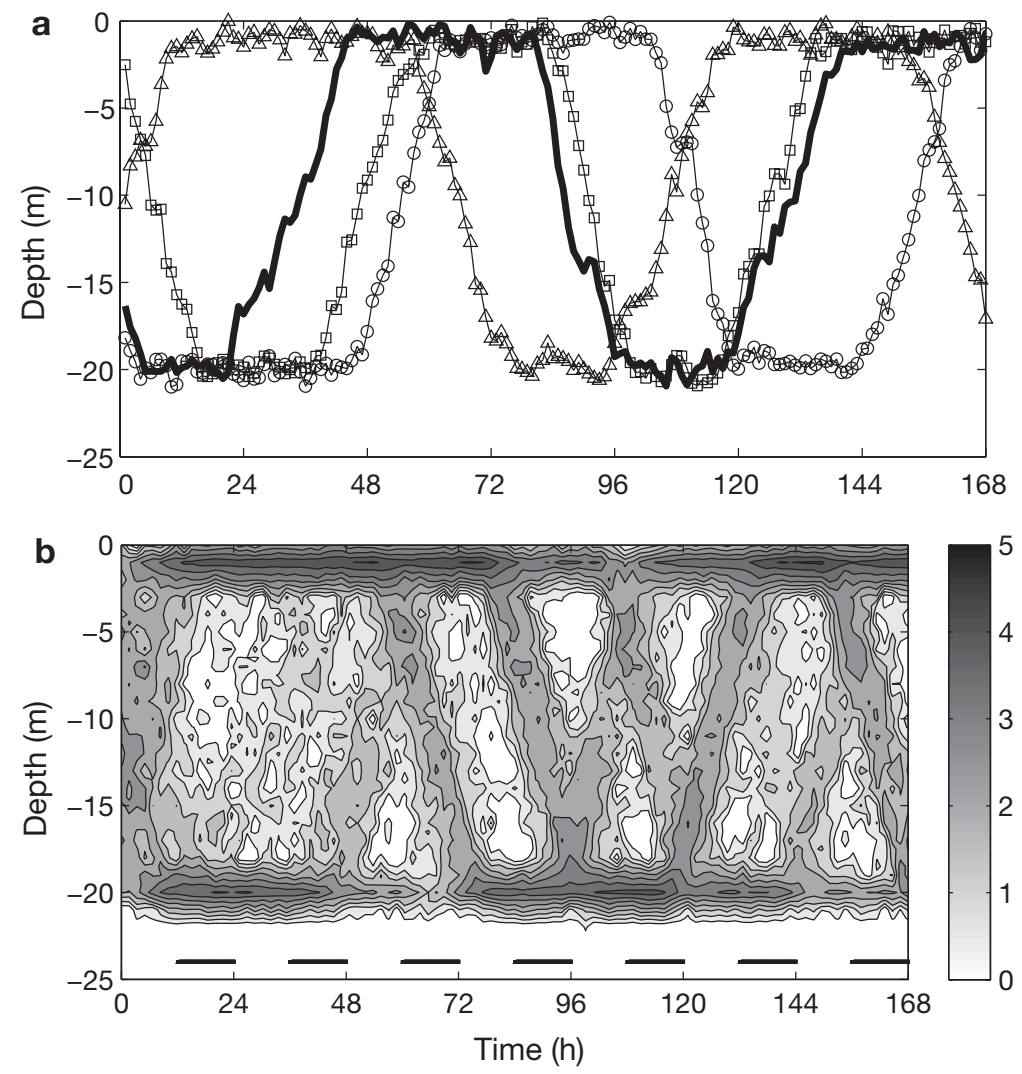

Fig. 5. Asynchronous vertical migration (AVM). (a) Example of trajectories of individual cells. (b) Bimodal distribution of cells. The values represented by the shade bar are log transformed using $\ln (\#+1)$, where \# is the no. of cells in a $1 \mathrm{~m}$ vertical bin. Black bars at the bottom of plot represent nighttime 
old. Additionally, the light limitation of nitrogen uptake was greatly relaxed by increasing $g_{0}$, allowing dark uptake to occur.

AVM tends to generate a bimodal vertical distribution of cells, with intermittent high cell concentrations at both the surface and subsurface (Fig. 5b). A comparison of the ANGR between the quota-based AVM case and the photo-/geotaxis DVM case (relative probability density vs. ANGR in Fig. 6) shows that with this model realization, the former can achieve a higher ANGR than the latter when the MLD is deep (MannWhitney $U$-test, $\mathrm{p}<0.01$ ) (Fig. 6b), but the difference is statistically less significant (Mann-Whitney $U$-test, p < 0.05) when the MLD is shallow (Fig. 6a). This result suggests that cells can take full advantage of luxury uptake of nitrogen by adopting the quota-based strategy with DVM in a shallow MLD. However, if the MLD becomes much deeper, cells may not be able to complete their commutes between surface and pycnocline in one day/night cycle, and AVM becomes more favorable. In both cases, however, the highest ANGR were achieved by AVM (the right-hand tails of the distri-

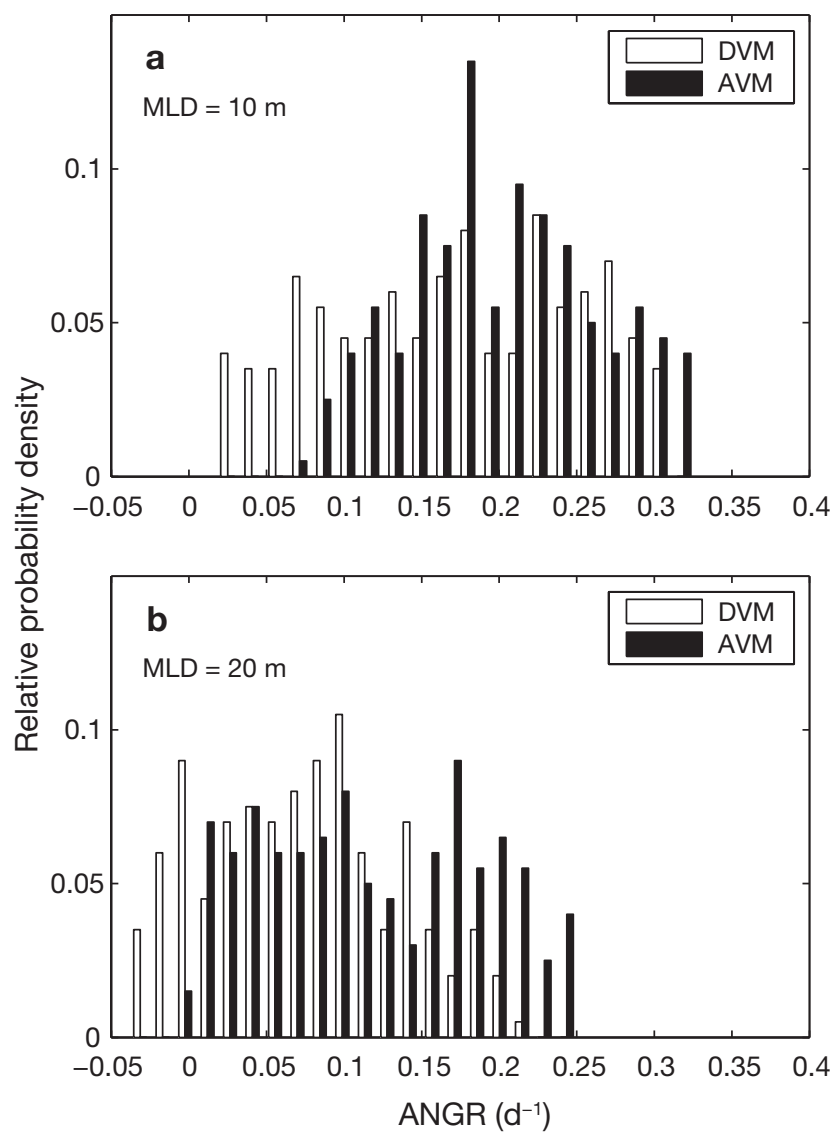

Fig. 6. Relative probability density functions (pdf) of average net growth rate (ANGR) for cells with DVM and AVM patterns. (a) $\mathrm{MLD}=10 \mathrm{~m}$; (b) $\mathrm{MLD}=20 \mathrm{~m}$ butions), suggesting that this strategy might favor the formation of dense blooms.

Case 2: Effect of internal waves

The vertical oscillation of the pycnocline with internal waves allows the dinoflagellate cells exposure to higher light levels near the wave crests, affecting the growth and internal quota dynamics. Here the effects of simple lunar semidiurnal $\left(\mathrm{M}_{2}\right)$ internal tidal waves were examined, with an understanding that in the real ocean, there exist internal waves with a range of frequencies. The mean pycnocline depth, $z_{\mathrm{m}}$, was set to $20 \mathrm{~m}$, and 2 different wave amplitudes (6 and $12 \mathrm{~m}$ ) were used.

With different initial phase differences $P_{\text {diff }}$ between the internal waves and the day/night cycle, the phytoplankton cells will experience different light fields with consequent effects on the nitrogen uptake and cell growth rate. With parameters for subsurface aggregation (Table 1, Set A), and an internal wave amplitude of $12 \mathrm{~m}$, the cells remain in a subsurface layer and oscillate vertically with the internal waves if $P_{\text {diff }}$ is $0.4 \pi$ (Case 2a: pycnocline is deepest near noon and midnight; Fig. 7a). If $P_{\text {diff }}$ is changed to $1.3 \pi$ (Case 2b: pycnocline is shallowest near noon and midnight), some cells start to move upward and reach the surface after the first day, resulting in a bimodal distribution by the end of the model run (Fig. 7b). This result shows that different internal waves can influence the cell quota dynamics in different ways. When $P_{\text {diff }}$ is $0.4 \pi$, the irradiance is in phase with the internal wave (deeper pycnocline occurs during high light intensity), and cells come close to following isolumes. When $P_{\text {diff }}=1.3 \pi$, cells acquire disproportionately more irradiance during the day as the wave brings them toward the surface; some take up nutrients and respire to the point that $Q>\gamma Q_{\max }$, and the cells ascend. Dinoflagellates with this wave phasing average a significantly lower mean ANGR compared to Cases 1 and 2a as shown in the relative probability density plot (Fig. 8) and Mann-Whitney $U$-test $(p<0.01)$. Even though the mean ANGR is lower in the internal wave Case $2 b$, the highest ANGRs are found in the internal wave cases, particularly Case 2a. With exponential growth, even small differences in net growth rate become hugely magnified over time, and most of the cells contributing to a bloom will come from the right-hand tail of the ANGR distributions. In this case it is the cells that moved to the surface, rather than remaining at the pycnocline. Thus the variance of ANGR-particularly the right-hand the tail of the distribution-is potentially more ecologically important than the mean.

The results shown above are based on a specific set of parameters defining the $P-I$ relationship, surface 

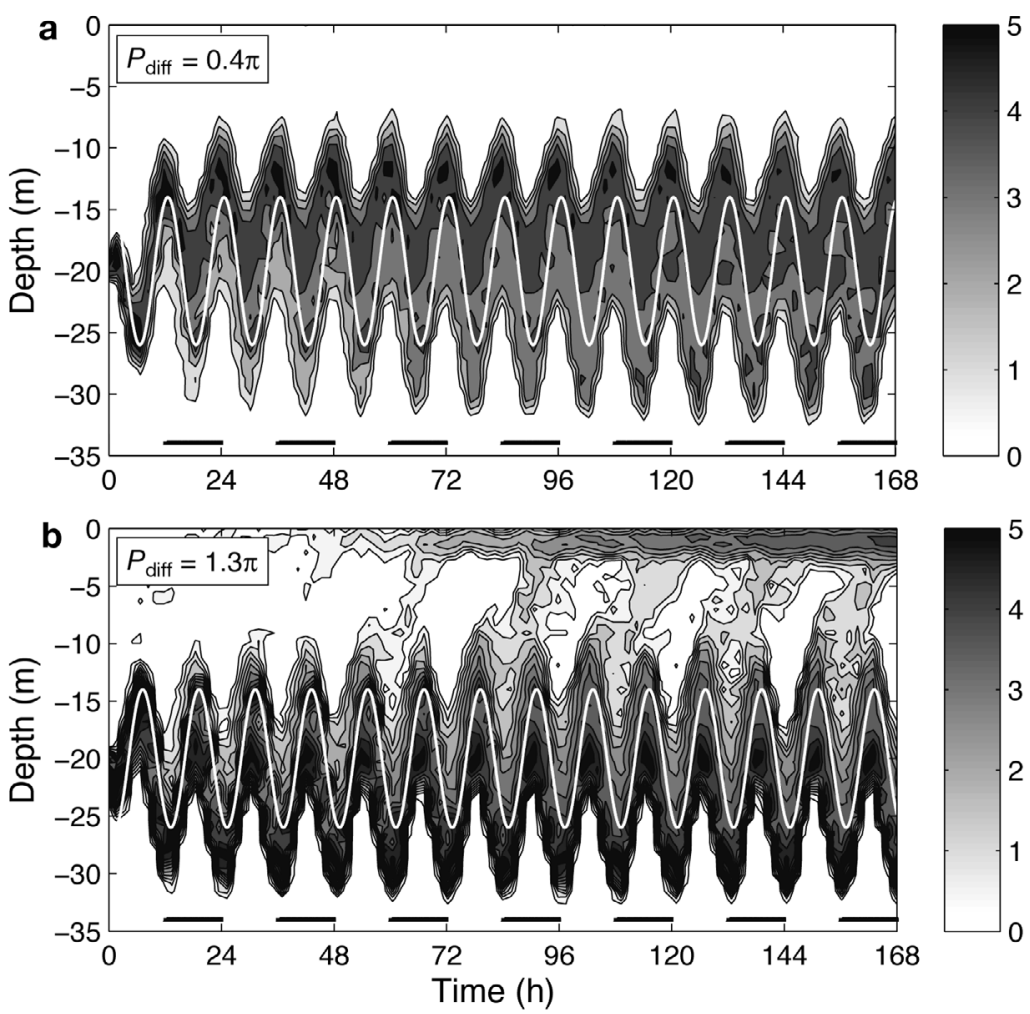

Fig. 7. Vertical distribution pattern with different initial phase differences $P_{\text {diff }}$ between the internal waves and the day/night cycle. (a) $P_{\text {diff }}=0.4 \pi$. (b) $P_{\text {diff }}=1.3 \pi$. Values represented by the shade bar are log transformed using $\ln (\#+1)$, where \# is the no. of cells in a $1 \mathrm{~m}$ vertical bin. Black bars at the bottom of plot represent nighttime. White curve represents the internal wave

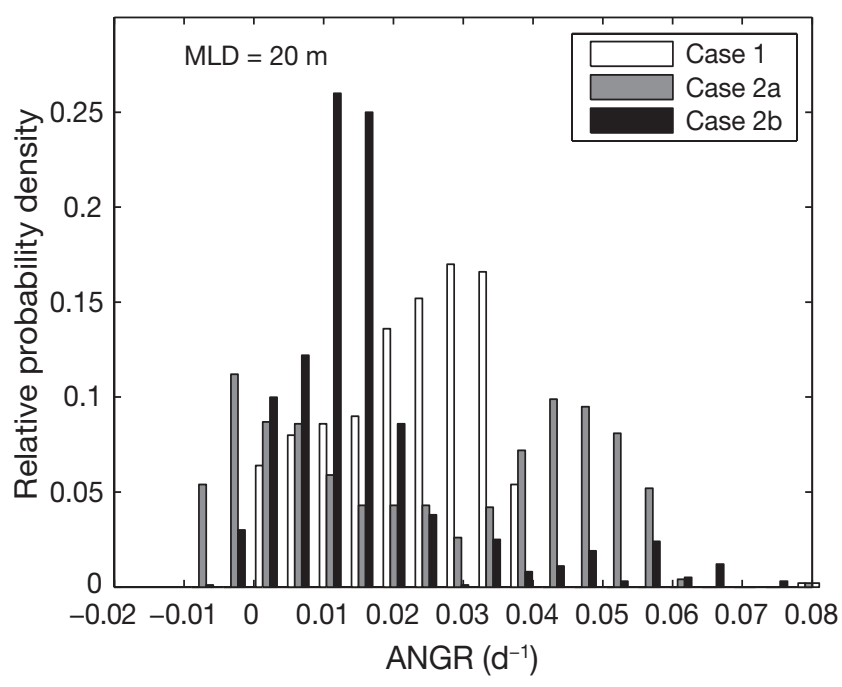

Fig. 8. Relative probability density functions (pdf) of average net growth rate (ANGR) for cells exposed to no internal wave (Case 1), an internal wave with $P_{\text {diff }}=0.4 \pi$ (Case 2a) and an internal wave with $P_{\text {diff }}=1.3 \pi($ Case $2 b)$ light intensity, $K_{\text {ext }}$ MLD, and internal wave amplitude. Our numerical experiments have shown that opposite results can be obtained with different sets of parameters, such as a shallower MLD and decreased $K_{\text {ext }}$ (results not shown here). The main point of this analysis is to show that internal waves can affect the vertical migration and resulting distribution patterns, and that these effects depend on the cell physiology and the physical environment. In the real ocean, the tidal amplitude and phase continue to change relative to the day/night cycle, suggesting that there may be a shift between the subsurface and bimodal distribution patterns.

Case 3: Effect of high light avoidance (HLA)

In this experiment, the photo-response of dinoflagellates cells was examined, focusing on the consequence of HLA. Photo-inhibition of photosynthesis was not included in this model; instead we assumed that inhibition can be minimized by HLA. The model used the same setting as for the AVM case, with an MLD of $20 \mathrm{~m}$ (Table 1, Set B). In addition, the cells perform HLA if the light intensity is higher than a threshold level of 200 or $400 \mu$ Ein $\mathrm{m}^{-2} \mathrm{~s}^{-1}$. Cells at a depth where the light intensity was higher than the threshold would simply migrate down and try to stay at a depth near the optimal light level.

With a threshold level of $200 \mu$ Ein $\mathrm{m}^{-2} \mathrm{~s}^{-1}$ (Fig. 9a), cells that were initially distributed uniformly through the mixing layer migrated down to avoid high irradiance during the peak daylight hours and moved up to the surface during the night. After about $3 d$, the cells were mostly aggregated between 5 and $18 \mathrm{~m}$, with the highest concentration near $15 \mathrm{~m}$. When the threshold level was $400 \mu$ Ein $\mathrm{m}^{-2} \mathrm{~s}^{-1}$ (Fig. 9b), an interesting distribution pattern appeared, with 2 subsurface maximum layers, 1 near the pycnocline at $20 \mathrm{~m}$, and the other near $10 \mathrm{~m}$. The higher threshold in this case allows cells to move higher in the water column during the day, altering the rate at which they change $Q$. These results suggest that HLA can have a strong influence on vertical migration and the consequent vertical distribution patterns. Presently, however, we lack the observational evidence to corroborate a subsurface maximum significantly above the pycnocline as shown in this model. This will be discussed further below. 

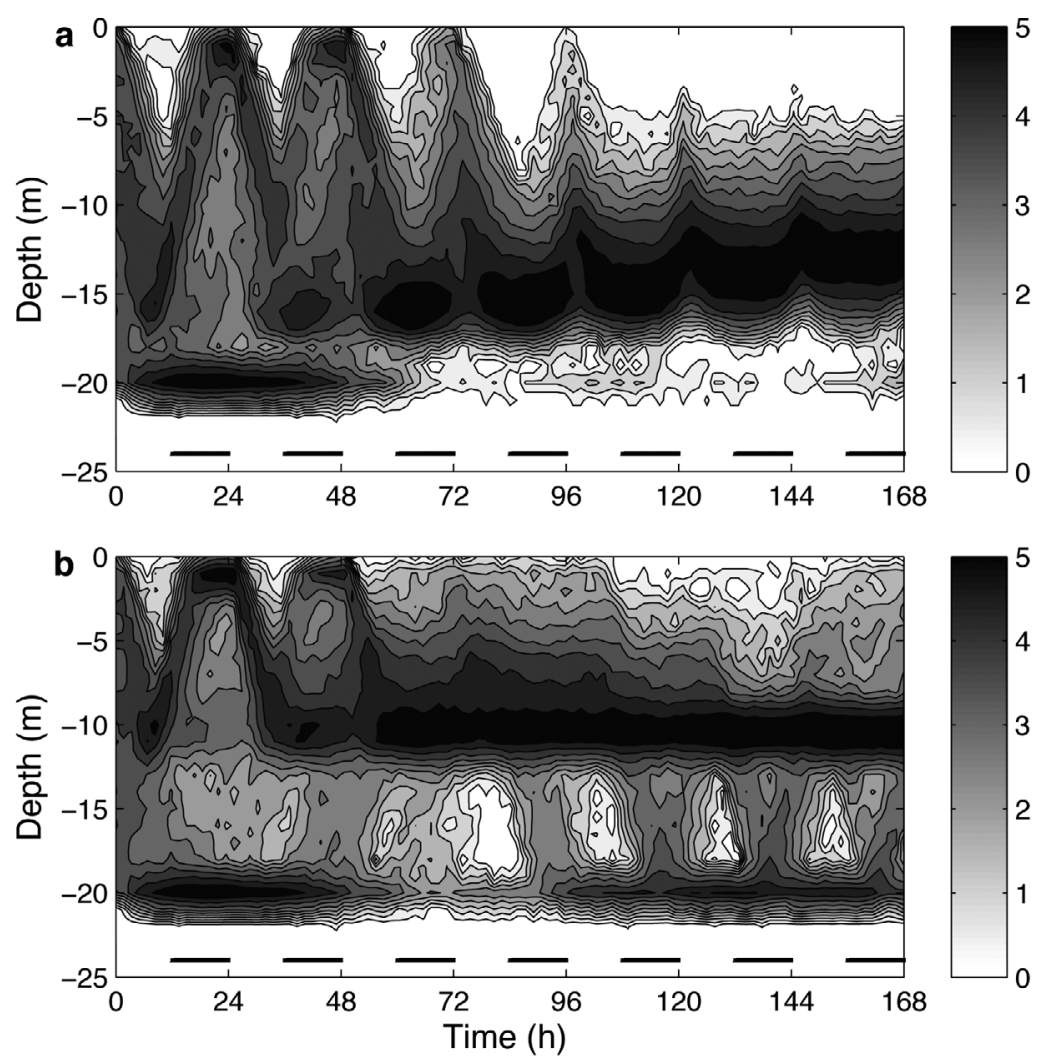

Fig. 9. Vertical distribution patterns when high light avoidance (HLA) by dinoflagellates is included in the model. (a) Light threshold set to $200 \mu$ Ein $\mathrm{m}^{-2} \mathrm{~s}^{-1}$, (b) light threshold set to $400 \mu$ Ein $\mathrm{m}^{-2} \mathrm{~s}^{-1}$. Values represented by the shade bar are log transformed using $\ln (\#+1)$, where \# is the number of cells in a $1 \mathrm{~m}$ vertical bin. Black bars at the bottom of plot represent nighttime

VM patterns for several coexisting species of dinoflagellates have been observed in coastal waters off southern California (Eppley et al. 1984), with Ceratium tripos aggregating subsurface, and DVM for other species (Prorocentrum micans, C. furca, and Gonyaulax polyedra = Lingulodinium polyedrum). The reason for this difference appears to be associated with the different physiologies of the individual species. It was argued that the irradiance at the depth of subsurface maximum may have been saturating for the photosynthesis of $C$. tripos with the help of semidiurnal internal tidal waves (amplitude 6 to $17 \mathrm{~m}$ ). However, at least 2 of the other 3 species appear to have much higher light requirements (Langdon 1988), preventing them from staying subsurface where irradiance is low. This is consistent with our model results: organisms that saturate at low light intensities tend to form subsurface aggregations through HLA.

It has also been widely reported that a given species of dinoflagellate can have different VM strategies in different mixing/stratification regimes. For example, Townsend et al. (2001, 2005) reported both subsurface aggregations and bimodal distributions (indicative of AVM) of Alexandrium sp. in the Gulf of Maine when the MLD was between 20 and $30 \mathrm{~m}$.

\section{DISCUSSION}

Through analytical and numerical models, we have shown that dinoflagellates should display a wide range of behaviors and consequent distribution patterns, depending on their physiological status and the environmental forcing. DVM was a viable strategy in shallow mixed layers, while subsurface aggregations or AVM tended to be favored in deeper mixed layers due to light limitation and the longer transit time from the surface to the bottom of the mixed layer. A wide range of strategies is apparent in mixed layers perturbed by internal waves: AVM and bimodal distribution patterns often appeared and depended on the phasing of the internal waves and the day/night cycle. HLA tended to lead to subsurface aggregations, although the details of the patterns (uni- or bimodal) depended on the irradiance threshold of the dinoflagellates and their initial positions in the water column.

Different species of dinoflagellate have unique strategies to coexist with other species under certain environmental constraints (Smayda 1997). Different
A DVM signal was detected by Fauchot et al. (2005) for the same species in the St. Lawrence estuary when the MLD was about $12 \mathrm{~m}$. Laboratory experiments (MacIntyre et al. 1997) have suggested that $A$. tamarense can change its VM strategies over a time scale of 1 to $2 \mathrm{~d}$. These observations have been reproduced by our models and can be explained by several factors. First, dinoflagellates under different MLDs are likely to achieve different ANGR, which will influence both the choice of migration strategy and the cell densities in layers. Second, internal waves with different phases can significantly change the VM pattern, causing a switch between AVM and subsurface aggregation. This might explain the existence of the 2 VM patterns for Alexandrium sp. in the Gulf of Maine at different times and locations of the surveys (Townsend et al. 2005). In addition, the deepening of the MLD can also prevent cells from conducting DVM due to limits on cell swimming capabilities. The swimming speeds of dinoflagellates fall in the range of 0.7 to $2 \mathrm{~m} \mathrm{~h}^{-1}$, suggesting that cells can only reach an MLD shallower than $24 \mathrm{~m}$ in half a day if a DVM strategy is used. 
It seems reasonable to assume that a dinoflagellate might use a VM strategy that allows it to attain its maximal growth potential, whether it is simply clock driven or in response to its internal physiological status. Modeling experiments conducted by Kamykowski \& Yamazaki (1997) suggested that cells with the latter strategy appear to have a higher cumulative primary production than the former one. However, the conclusion could depend strongly on the environmental conditions and the specific physiological parameters/ thresholds used in the model, as suggested by our model results. Moreover, numerous observations have suggested that cells might not simply use a VM strategy based on maximizing growth potential. This is most obvious in the subsurface aggregation cases. For example, Rasmussen \& Richardson (1989) observed that Alexandrium tamarense accumulated near the pycnocline where the light intensity $\left(37 \mu\right.$ Ein $\left.\mathrm{m}^{-2} \mathrm{~s}^{-1}\right)$ was much lower than the optimal intensity $(>400 \mu$ Ein $\mathrm{m}^{-2} \mathrm{~s}^{-1}$ ). Through controlled experiments, they found that cells accumulated at the highest available light intensity when no pycnocline was present, which argues against light being the controlling factor in the pycnocline accumulation. A similar phenomenon was observed by Kononen et al. (2003), who found that Heterocapsa triquetra Ehrenb. aggregated near the nutricline at a depth of 30 to $35 \mathrm{~m}$, where the light intensity was $<0.1 \%$ of the surface PAR. Even for Ceratium tripos mentioned above (Eppley et al. 1984), experiments conducted by Malone (1978) suggested that the growth rate could be significantly increased ( $\sim 10$ fold) if the cells were exposed to a higher light environment. In 1 case of this modeling study (Fig. 4b), cells remained subsurface due to the quota limitation, although cells appeared to perform better in terms of ANGR if a DVM strategy was chosen, given the $20 \mathrm{~m}$ MLD. The model results also suggested that subsurface aggregations could not be explained solely by a photo-response behavior (HLA). Cells tended to move to positions not matching with the pycnoclines if the migration behavior was controlled by HLA only (Fig. 9). This is different from the typical scenario, in which subsurface maxima are frequently observed near the pycnoclines. Therefore, we argue that at least in some cases, subsurface aggregations are mediated by physiological properties such as the cell quota; the nitrogen quota requirement forces cells to stay subsurface.

Acknowledgements. R.J. received support from the WHOI Penzance Assistant Scientist Fund and NOAA grant NA17RJ1223. The support for P.J.S.F. was from NSF grant OCE0220379 and ONR grant N00014-06-0304. Three anonymous reviewers made suggestions that helped improve the manuscript. Discussion with C. Davis was very inspirational. This is US GLOBEC contribution number 520.

\section{LITERATURE CITED}

Broekhuizen N (1999) Simulating motile algae using a mixed Eulerian-Lagrangian approach: does motility promote dinoflagellate persistence or co-existence with diatoms? J Plankton Res 21:1191-1216

Cullen JJ (1985) Diel vertical migration by dinoflagellates: roles of carbohydrate metabolism and behavioral flexibility. Contrib Mar Sci Suppl 27:135-152

Cullen JJ, Horrigan SG (1981) Effects of nitrate on the diurnal vertical migration, carbon to nitrogen ratio, and the photosynthetic capacity of the dinoflagellate Gymnodinium splendens. Mar Biol 62:81-89

Cullen JJ, Zhu M, Davis RF, Pierson DC (1985) Vertical migration, carbohydrate synthesis, and nocturnal nitrate uptake during growth of Heterocapsa niei in a laboratory water column. In: Anderson DM, White AW, Baden DG (eds) Toxic dinoflagellates. Elsevier, Amsterdam, p 189-194

Droop MR (1968) Vitamin B12 and marine ecology. IV. The kinectics of uptake, growth and inhibition in Monochrysis lutheri. J Mar Biol Assoc UK 48:689-733

Eppley RW, Harrison WG (1975) Physiological ecology of Gonyaulax polyedra: A red water dinoflagellate of southern California. In: LoCicero VR (ed) Proc 1st Int Conf Tox Dinoflagellate Blooms. Mass Sci Tech Found, Wakefield, MA, p 11-22

Eppley RW, Holm-Hansen O, Strickland JDH (1968) Some observations on the vertical migration of dinoflagellates. J Phycol 4:333-340

Eppley RW, Reid RMH, Cullen JJ, Winant CD, Stewart E (1984) Subsurface patch of a dinoflagellate (Ceratium tripos) off Southern California: patch length, growth rate, associated vertically migrating species. Mar Biol 80:207-214

Fan CL, Glibert PM (2005) Effects of light on nitrogen and carbon uptake during a Prorocentrum minimum bloom. Harmful Algae 4:629-641

Fauchot J, Levasseur M, Roy S (2005) Daytime and nighttime vertical migrations of Alexandrium tamarense in the St. Lawrence estuary (Canada). Mar Ecol Prog Ser 296: 241-250

Flynn KJ, Fasham MJR (2002) A modelling exploration of vertical migration by phytoplankton. J Theor Biol 218:471-484

Fraga F, Perez FF, Figueiras FG, Rios AF (1992) Stoichiometric variations of $\mathrm{N}, \mathrm{P}, \mathrm{C}$ and $\mathrm{O}_{2}$ during a Gymnodinium catenatum red tide and their interpretation. Mar Ecol Prog Ser 87:123-134

Franks PJS (1992) Sink or swim: accumulation of biomass at fronts. Mar Ecol Prog Ser 82:1-12

Franks PJS (1997) Spatial patterns in dense algal blooms. Limnol Oceanogr 42:1297-1305

Geider RJ, MacIntyre HL, Kana TM (1998) A dynamic regulatory model of phytoplanktonic acclimation to light, nutrients, and temperature. Limnol Oceanogr 43:679-694

Heaney SI, Eppley RW (1981) Light, temperature and nitrogen as interacting factors affecting diel vertical migrations of dinoflagellates in culture. J Plankton Res 3:331-344

Holligan PM, Balch WM, Yentsch CM (1984) The significance of subsurface chlorophyll, nitrite and ammonium maxima in relation to nitrogen for phytoplankton growth in stratified waters of the Gulf of Maine. J Mar Res 42:1051-1073

Holmes RW, Williams PM, Eppley RW (1967) Red water in La Jolla Bay, 1964-1966. Limnol Oceanogr 12:503-512

Jassby AD, Platt T (1976) Mathematical formulation of the relationship between photosynthesis and light for phytoplankton. Limnol Oceanogr 21:540-547

Jones RI (1993) Phytoplankton migrations: patterns, processes and profits. Arch Hydrobiol Beih Ergeb Limnol 39:67-77 
Kamykowski D (1974) Possible interactions between phytoplankton and semidiurnal internal tides. J Mar Res 32: 67-89

Kamykowski D (1995) Trajectories of autotrophic marine dinoflagellates. J Phycol 31:200-208

Kamykowski D, Yamazaki H (1997) A study of metabolisminfluence orientation in the diel vertical migration of marine dinoflagellates. Limnol Oceanogr 42:1189-1202

Kamykowski D, Yamazaki H, Yamazaki AK, Kirkpatrick GJ (1998a) A comparison of how different orientation behaviors influence dinoflagellate trajectories and photoresponses in turbulent water columns. In: Anderson DM, Cembella AD, Hallegraeff GM (eds) Physiological ecology of harmful algal blooms. Springer Verlag, Berlin

Kamykowski D, Milligan EJ, Reed RE (1998b) Relationships between geotaxis/phototaxis and diel vertical migration in autotrophic dinoflagellates. J Plankton Res 20:1781-1796

Kononen K, Huttunen M, Hallfors S, Gentien P and 6 others (2003) Development of a deep chlorophyll maximum of Heterocapsa triquetra Ehrenb. at the entrance to the Gulf of Finland. Limnol Oceanogr 48:594-607

Kudela RM, Cochlan WP (2000) Nitrogen and carbon uptake kinetics and the influence of irradiance for a red tide bloom off southern California. Aquat Microb Ecol 21: $31-47$

Langdon C (1988) On the causes of interspecific differences in the growth irradiance relationship for phytoplankton 2. A general review. J Plankton Res 10:1291-1312

Liu G, Janowitz GS, Kamykowski D (2001) A biophysical model of population dynamics of the autotrophic dinoflagellate Gymnodinium breve. Mar Ecol Prog Ser 210: 101-124

MacIntyre JG, Cullen JJ, Cembella AD (1997) Vertical migration, nutrition and toxicity in the dinoflagellate Alexandrium tamarense. Mar Ecol Prog Ser 148:201-216

Malone TC (1978) Ceratium tripos bloom in the New York Bight: causes and consequences. Circ US Natl Mar Fish Serv (US Dep Comm) 410:1-14

Olsson P, Graneli E (1991) Observations on diurnal vertical migration and phased cell-division for 3 coexisting marine dinoflagellates. J Plankton Res 13:1313-1324

Paasche E, Bryceson I, Tangen K (1984) Interspecific variation in dark nitrogen uptake by dinoflagellates. J Phycol 20: $394-401$

Pearre S (2003) Eat and run? The hunger/satiation hypothesis in vertical migration: history, evidence and consequences. Biol Rev 78:1-79

Prezelin BB (1992) Diel periodicity in phytoplankton productivity. Hydrobiologia 238:1-35

Rasmussen J, Richardson K (1989) Response of Gonyaulax tamarensis to the presence of a pycnocline in an artificial water column. J Plankton Res 11:747-762

Ross ON, Sharples J (2004) Recipe for 1D Lagrangian particle tracking models in space-varying diffusivity. Limnol Oceanogr Methods 2:289-302

Smayda TJ (1997) Harmful algal blooms: their ecophysiology and general relevance to phytoplankton blooms in the sea. Limnol Oceanogr 42:1137-1153

Townsend DW, Pettigrew NR, Thomas AC (2001) Offshore blooms of the red tide dinoflagellate, Alexandrium sp., in the Gulf of Maine. Cont Shelf Res 21:347-369

Townsend DW, Bennett SL, Thomas MA (2005) Diel vertical distributions of the red tide dinoflagellate Alexandrium fundyense in the Gulf of Maine. Deep-Sea Res II 52: 2593-2602

Villarino ML, Figueiras FG, Jones KJ, Alvarez-Salgado XA, Richard J, Edwards A (1995) Evidence of in situ diel vertical migration of a red-tide microplankton species in Ria de Vigo (NW Spain). Mar Biol 123:607-617

Visser AW (1997) Using random walk models to simulate the vertical distribution of particles in a turbulent water column. Mar Ecol Prog Ser 158:275-281

Watanabe M, Kohata K, Kimura T (1991) Diel vertical migration and nocturnal uptake of nutrients by Chattonella antiqua under stable stratification. Limnol Oceanogr 36:593-602

Yamazaki AK, Kamykowski D (2000) A dinoflagellate adaptive behavior model: response to internal biochemical cues. Ecol Model 134:59-72 
Appendix 1. Derivations for the vertical migration time scales given in Eqs. (9) \& (10) and the conditions necessary for the formation of subsurface aggregations described in Eq. (11)

\section{Derivation of Eqs. (9) \& (10) for quota-based DVM}

Dinoflagellates conducting DVM solely in response to changes in the nitrogen quota requires them to increase their cell nitrogen quota during the night and to decrease it during the day. We will first consider the conditions for upward migration: $Q$ must have increased to near its maximum. Since we expect upward migration to be controlled by processes occurring during the previous night, we can set $g(I)=1$, and $f(I)=0$. Assuming further that the nitrate concentration is saturating, we can rewrite Eq. (8) as:

$$
\frac{\mathrm{d} Q}{\mathrm{~d} t}=V_{\mathrm{m}} \frac{Q_{\max }-Q}{\Delta Q}+\lambda Q
$$

From this equation, it is clear that there are 2 ways of increasing $Q$ at night: by taking up nitrogen and by respiring carbon. To simplify the algebra, we will first consider the initial condition $Q(0)=Q_{\min }$, with upward migration occurring when $Q=$ $Q_{\max }$ some time $\tau_{\text {dark }}$ later. Solving Eq. (9), we obtain:

$$
Q=\frac{V_{\mathrm{m}} Q_{\max }}{V_{\mathrm{m}}-\lambda \Delta Q}+\left(Q_{\min }-\frac{V_{\mathrm{m}} Q_{\max }}{V_{\mathrm{m}}-\lambda \Delta Q}\right) \exp \left[-\left(\frac{V_{\mathrm{m}}}{\Delta Q}-\lambda\right) \tau_{\text {dark }}\right]
$$

The ascent phase of the DVM will occur when $Q=Q_{\max }$, which means:

$$
Q=\frac{V_{\mathrm{m}} Q_{\max }}{V_{\mathrm{m}}-\lambda \Delta Q}+\left(Q_{\min }-\frac{V_{\mathrm{m}} Q_{\max }}{V_{\mathrm{m}}-\lambda \Delta Q}\right) \exp \left[-\left(\frac{V_{\mathrm{m}}}{\Delta Q}-\lambda\right) \tau_{\text {dark }}\right]=Q_{\max }
$$

or,

$$
\tau_{\text {dark }}=-\left(\frac{V_{\mathrm{m}}}{\Delta Q}-\lambda\right)^{-1} \ln \left[\frac{\lambda Q_{\max }}{V_{\mathrm{m}}+\lambda Q_{\min }}\right]
$$

This time will be shorter if respiration $\lambda$ is low relative to uptake. If $\lambda>V_{\mathrm{m}} / \Delta Q$, then the rate of change of $Q$ must increase in time to obtain a real $\tau$. In this case, the increase in $Q$ would be caused mainly by respiration of carbon, rather than uptake of nitrogen.

If we relax our assumption that $Q(0)=Q_{\min }$ and $Q(t)=Q_{\max }$, and instead use $Q(0)=\sigma Q_{\min }$, and $Q\left(\tau_{\text {dark }}\right)=\gamma Q_{\max }$, with $\sigma>1$ $>\gamma>Q_{\min } / Q_{\max }$, we obtain a solution for $\tau_{\text {dark }}$ similar to Eq. (A4):

$$
\tau_{\text {dark }}=-\left(\frac{V_{\mathrm{m}}}{\Delta Q}-\lambda\right)^{-1} \ln \left[\frac{\frac{V_{\mathrm{m}}}{V_{\mathrm{m}}-\lambda \Delta Q}-\gamma}{\frac{V_{\mathrm{m}}}{V_{\mathrm{m}}-\lambda \Delta Q}-\frac{Q_{\min }}{Q_{\max }} \sigma}\right]
$$

We can perform a similar analysis for the decrease in $Q$ during the daytime, when growth decreases $Q$ while respiration increases it. If we assume $f(I)=1$ (best case) and nitrogen uptake close to 0 due to the depleted nitrogen at the surface, we can rewrite Eq. (8) as:

$$
\frac{\mathrm{d} Q}{\mathrm{~d} t}=-\mu_{\max }\left(Q-Q_{\min }\right)+\lambda Q
$$

Using a similar scenario as above with an initial value of $Q(0)=\gamma Q_{\max }$ and a final value of $Q\left(\tau_{\text {light }}\right)=\sigma Q_{\min }$, we find:

$$
\begin{array}{r}
Q=\left(\gamma Q_{\min }-\frac{\mu_{\max }}{\mu_{\max }-\lambda} Q_{\min }\right) \exp \left[-\left(\mu_{\max }-\lambda\right) \tau_{\text {light }}\right]+ \\
\frac{\mu_{\max }}{\mu_{\max }-\lambda} Q_{\min }=\sigma Q_{\min }
\end{array}
$$

This gives a time scale $\tau_{\text {light }}$ for the decrease of $Q$ during the day:

$$
\tau_{\text {light }}=-\left(\mu_{\max }-\lambda\right)^{-1} \ln \left[\frac{\sigma-\frac{\mu_{\max }}{\mu_{\max }-\lambda}}{\frac{Q_{\max }}{Q_{\min }} \gamma-\frac{\mu_{\max }}{\mu_{\max }-\lambda}}\right]
$$

\section{Derivation of Eq. (11) for the quota-based subsurface aggregation}

Cells initially subsurface (near the nitracline) with nitrogen quota $Q<\gamma Q_{\max }$ will remain there if the nitrogen quota $Q$ can be maintained less than $\gamma Q_{\max }$. During the night, nitrogen uptake and cell respiration tend to increase $Q$. To keep $Q<\gamma Q_{\max }$ and remain subsurface, a decrease of $Q$ during the day is required to balance the increase during the night. It is thus necessary that the following condition to be satisfied under at least one PAR level (I) during the daytime,

$$
\tilde{V} \frac{Q_{\max }-Q}{\Delta Q} g(I)<\lambda Q+\tilde{V} \frac{Q_{\max }-Q}{\Delta Q} g(I) \leq \mu_{\max }\left(Q-Q_{\min }\right) f(I)
$$

where

$$
\tilde{V}=V_{\mathrm{m}} \frac{N}{\mathrm{~K}_{N}+N}
$$

This requires

$$
\frac{f(I)}{g(I)} \geq \frac{\tilde{V}\left(Q_{\max }-Q\right)}{\mu_{\max }\left(Q-Q_{\min }\right) \Delta Q}
$$
Noting that $Q<\gamma Q_{\max }$, and $\frac{f(I)}{g(I)} \leq 1$, we can let $Q_{\max }=\varepsilon Q_{\min }$,
to show:

$$
1 \geq \frac{f(I)}{g(I)} \geq \frac{\tilde{V}}{\mu_{\max } Q_{\min }} \frac{(1-\gamma)}{(\gamma-1 / \varepsilon)(\varepsilon-1)}
$$

Under conditions with sufficient ambient light and nutrients, $\tilde{V} \rightarrow V_{\mathrm{m}}$, giving the dimensionless number:

$$
\psi=\frac{\tilde{V}}{Q_{\min } \mu_{\max }} \approx \frac{V_{\mathrm{m}}}{Q_{\min } \mu_{\max }}
$$

which represents the relationship between maximum nitrogen uptake rate and growth rate. For cells to remain subsurface, $\psi$ must satisfy:

$$
\psi=\frac{V_{\mathrm{m}}}{Q_{\min } \mu_{\max }} \leq \frac{(\gamma-1 / \varepsilon)(\varepsilon-1)}{(1-\gamma)}
$$

Notice in Eq. (A12), if $g(I)$ is close to $f(I)$, meaning nitrogen uptake is more light-dependent than growth, then less nitrogen will be taken up in the low-light subsurface environment, which will actually facilitate the satisfaction of the condition in Eq. (A13). 